\title{
THE EFFECT OF DISCHARGE PLANNING ON TREATMENT ADHERENCE AMONG THE ELDERLY WITH HYPERTENSION IN BANJARMASIN, SOUTH KALIMANTAN
}

\author{
Candra Kusuma Negara
}

Study Program in Nursing, School of Health Sciences Cahaya Bangsa, Banjarmasin

\begin{abstract}
Background: Discharge planning is a process that aims to improve the coordination of services after discharge from hospital by considering the patient's needs in the community. It involves the patient, carer, family, and any staff involved in the patient's care. The aim of discharge planning is to ensure a safe and smooth discharge from hospital - whether to home, residential care or another location. This study aimed to assess the effect of discharge planning on patient adherence to treatment.

Subjects and Method: This was a quasi-experiment before and after with no control design. This study was conducted at Ulin general hospital, Banjarmasin, South Kalimantan. A sample of 20 elderly patients with hypertension was selected for this study. The dependent variable was adherence to treatment. The independent variable was discharge planning. The data were collected by questionnaire. Difference in mean adherence before and after discharge planning was tested by ttest.

Results: Mean adherence to treatment was higher after discharge planning $(\mathrm{Mean}=25.27 ; \mathrm{SD}=4.46)$ than before discharge planning (Mean=15.20; $\mathrm{SD}=$ 3.05), and it was statistically significant $(\mathrm{p}=0.027)$.

Conclusion: Discharge planning is effective to increases adherence to treatment among patients with hypertension.

Keywords: discharge planning, family centered nursing, adherence to treatment, elderly patients, hypertension

\section{Correspondence:}

Candra Kusuma Negara. Study Program in Nursing, School of Health Sciences Cahaya Bangsa, Banjarmasin, South Kalimantan. Email: cknegara@stikescb.ac.id. Mobile: 085252852701.
\end{abstract}

